\title{
PERBANDINGAN RERATA EKSPRESI BCl-2 DAN BCI-XL PADA PREEKLAMSIA BERAT DAN KEHAMILAN NORMOTENSI
}

\author{
Budi Arianto ${ }^{1}$, Diah Rumekti $\mathrm{H}^{2}$, Detty S Nurdiati ${ }^{3}$
}

\begin{abstract}
Background: The state of hypoxia in severe preeclampsia cause placental oxidative stress that can lead excessive trophoblast apoptosis through the mitochondrial pathway. Apoptosis stimuli occurs through modulation of $\mathrm{p} 53$ and $\mathrm{Bcl}-2$ family expression which has antiapoptosis and proapoptosis function. Antiapoptosis protein consist of $\mathrm{Bcl}-2$ and $\mathrm{Bcl}-\mathrm{XL}$ and is expressed lower in apoptosis.

Objective: To compare the mean difference of the expression of antiapoptosis proteins Bcl-2 \& Bcl-XL and identify the type of protein that can be used as indicators of increased apoptosis.

Method: A cross-sectional study which consisted of 43 severe preeclampsia pregnancies and 38 third trimester normotensive pregnancies, recruited between October 2011 - March 2012. Observation of protein expression $\mathrm{Bcl}-2$ and $\mathrm{Bcl}-\mathrm{XL}$ used immunohistochemical techniques. Statistical analysis applied independent $t$ test $(P<0.05)$.

Result and Discussion: There were significant differences $(p<0.05)$ between the mean expression of Bcl-2 protein in trophoblast tissue among severe preeclampsia group $(1.03 \pm 0.04)$ compared to normotensive group $(1.10 \pm 0.08)$. The mean expression of $\mathrm{Bcl}-\mathrm{XL}$ protein in trophoblast tissue severe preeclampsia group $(1.29 \pm 0.12)$ compared to normotensive group $(1.71 \pm 0.14)$ were significantly difference $(p<0.05)$. The mean difference in protein expression of $\mathrm{Bcl}-2$ (0076; $95 \% \mathrm{Cl} 0.046$ to 0.104$)$ was lower than $\mathrm{Bcl}-\mathrm{XL}$ protein (0.42; $95 \% \mathrm{Cl} 0.47$ to 0.36$)$. The mean protein expression of $\mathrm{Bcl}-2$ and $\mathrm{Bcl}-\mathrm{XL}$ were lower in severe preeclampsia group compared with normotensive group, either in preterm or full-term gestation age with $p$ value $<0.05$.

Conclusion: The mean difference in protein expression of $\mathrm{Bcl}-2$ and $\mathrm{Bcl}-\mathrm{XL}$ is lower in severe preeclampsia pregnancies than normotensive pregnancies. The mean difference in protein expression of $\mathrm{Bcl}-2$ is lower than $\mathrm{BCl}-\mathrm{XL}$. Severe preeclampsia affects protein expression of $\mathrm{Bcl}-2$ and $\mathrm{Bcl}-\mathrm{XL}$ more than influence of gestational age.
\end{abstract}

Keywords: severe preeclampsia, trophoblast, Bcl-2, Bcl-XL, apoptosis.

\begin{abstract}
ABSTRAK
Latar belakang: Keadaan hipoksia pada preeklamsia berat akan menyebabkan stress oksidatif plasenta yang dapat memicu terjadi peningkatan apoptosis trofoblas melalui jalur mitokondria. Stimulus apoptosis terjadi melalui modulasi ekspresi P53 dan ekspresi protein $\mathrm{Bcl}-2$ family yang memiliki fungsi antiapoptosis dan proapoptosis. Protein antiapoptosis terdiri atas $\mathrm{Bcl}-2$ dan $\mathrm{Bcl}-\mathrm{XL}$ akan diekspresikan lebih rendah pada keadaan apoptosis.

Tujuan: Untuk melihat perbedaan rerata ekspresi protein antiapoptosis $\mathrm{Bcl}-2$ dan $\mathrm{Bcl}-\mathrm{XL}$ dan mengidentifikasi jenis protein yang dapat dijadikan indikator peningkatan apoptosis.

Metode: Rancangan penelitian ini potong lintang dengan populasi penderita kehamilan preeklamsia berat dan normotensi yang dirawat di RSUP Sardjito antara bulan Oktober 2011 hingga Maret 2012. Didapatkan sampel plasenta sebanyak 43 kehamilan preeklamsia berat dan 38 kehamilan normotensi. Pengamatan ekspresi protein $\mathrm{Bcl}-2$ dan $\mathrm{Bcl}-\mathrm{XL}$ dengan teknik imunohistokimia. Analisis statistik menggunakan independent $t$ test $(p<0.05)$.
\end{abstract}

1,2,3 Bagian Obstetri dan Ginekologi FK UGM/RSUP Dr. Sardjito, Yogyakarta 
Hasil dan Pembahasan: Terdapat perbedaan yang bermakna $(p<0,05)$ rerata ekspresi protein $\mathrm{Bcl}-2$ pada jaringan trofoblas kelompok kehamilan preeklamsia berat $(1,03 \pm 0,04)$ dibandingkan kelompok kehamilan normotensi $(1,10 \pm 0,08)$. Terdapat perbedaan yang bermakna $(p<0.05)$ rerata ekspresi protein $\mathrm{Bcl}-\mathrm{xL}$ pada jaringan trofoblas kelompok kehamilan preeklamsia berat $(1,29 \pm 0,12)$ dibandingkan kelompok kehamilan normotensi $(1,71 \pm 0,14)$. Beda rerata ekspresi protein untuk $\mathrm{Bcl}-2(0,076 ; \mathrm{Cl} 95 \% 0,046-0,104)$ lebih rendah dibandingkan beda rerata ekspresi protein $\mathrm{Bcl}-\mathrm{xL}(0,42 ; \mathrm{Cl} 95 \%$ 0,47- 0,36). Rerata ekspresi protein $\mathrm{Bcl}-2$ dan $\mathrm{Bcl}-\mathrm{XL}$ lebih rendah pada kelompok preeklamsia berat dibandingkan dengan normotensi baik pada umur kehamilan preterm maupun aterm yang ditunjukkan dengan nilai $p<0,05$.

Kesimpulan: Beda rerata ekspresi protein $\mathrm{Bcl}-2$ dan $\mathrm{Bcl}-\mathrm{xL}$ lebih rendah pada kehamilan preeklamsia berat dibandingkan kehamilan normotensi. Beda rerata ekspresi protein $\mathrm{Bcl}-2$ lebih rendah dibandingkan beda rerata ekspresi protein $\mathrm{Bcl}-\mathrm{xl}$. Preeklamsia berat lebih berpengaruh terhadap ekspresi protein $\mathrm{Bcl}-2$ dan $\mathrm{Bcl}-\mathrm{XL}$ dibandingkan umur kehamilan

Kata Kunci: preeklamsia berat, trofoblas, protein $\mathrm{Bcl}-2$, protein $\mathrm{Bcl}-\mathrm{xl}$, apoptosis

\section{PENDAHULUAN}

Di Indonesia, angka kejadian preeklampsia pada tahun 1980-2001 berkisar antara 5-8\% dari seluruh kehamilan. Di RSUP DR. Sardjito angka kematian maternal karena preeklampsiaeklampsia adalah sebesar 34,09\%. Di RSU Dr. Saiful Anwar tahun 2006 terdapat sekitar 321 kasus preeklampsia dan 72 kasus eklampsia dari 2588 persalinan. Angka kejadian preeklampsia di RSUP. H. Adam Malik dan RSU. Dr. Pirngadi Medan periode $2000-2003$ adalah 5,94\%, sedangkan eklampsia $1,07 \%$. 1,2,3,4

Preeklampsia sampai saat ini masih merupakan disease of theory. Berbagai macam penelitian belum dapat menerangkan dengan jelas penyebab pasti preeklampsia. Akibatnya sampai saat ini belum ada pengobatan definitif pada kelainan ini. Banyak teori telah dikemukakan tentang terjadinya hipertensi dalam kehamilan namun tidak satu pun teori tersebut yang dianggap mutlak benar. ${ }^{5}$

Bcl-2 family dapat mengatur sinyal kematian baik secara langsung atau diinisiasi melalui jalur instrinsik dalam pengaturan pelepasan faktorfaktor proapoptosis dari mitokondria. $\mathrm{Bcl}_{2}$ dan $\mathrm{Bcl}_{\mathrm{xL}}$ adalah kelompok antiapoptosis yang menghambat pelepasan sitokrom c dan faktorfaktor proapotosis lain dari mitokondria, yang selanjutnya mencegah perjalanan lebih lanjut dari sinyal apoptosis. Ketika sel kehilangan sinyal untuk bertahan hidup atau mengalami stres, $\mathrm{Bcl}_{2}$ dan $\mathrm{Bcl}_{\mathrm{XL}}$ akan hilang dari membran mitokondria dan digantikan oleh anggota famili proapoptosis (Bax, Bak dan Bim). Dengan penurunan kadar Bcl${ }_{2}$ dan $\mathrm{BCl}_{\mathrm{XL}^{\prime}}$ permeabilitas membran mitokondria meningkat, selanjutnya akan terjadi pelepasan faktor-faktor proapotosis seperti sitokrom c, smac/DIABLO, omi melalui pori-pori mitokondria yang disebut Permeability Transition Pore (PTP/ PT Pore). Pelepasan sitokrom c dari mitokondria memainkan peranan penting dalam induksi apoptosis. Begitu sitokrom c dilepaskan ke sitosol maka akan mampu berinteraksi dengan protein yang disebut dengan Apaf-1. Bersama dengan pro-caspase 9 dan komplek multi protein dengan sitokrom c dan Apaf-1 akan membentuk suatu apoptosome. Formasi apoptosome ini akan mengaktivasi caspase 9 dan selanjutnya caspase 9 akan mengaktifasi caspase 3 sebagai caspase eksekusioner. ${ }^{6,7}$

Dari kedua kelompok antiapotosis $\mathrm{Bcl}_{2}$ dan $\mathrm{Bcl}_{\mathrm{XL}^{\prime}}$, sama-sama diekspresikan lebih rendah 
(down regulation) pada proses apoptosis. Sejauh ini menarik untuk diketahui dari kedua protein antiapotosis tersebut, apakah ekspresi kedua protein tersebut mengalami tingkat penurunan yang sama atau hanya salah satu dari kedua protein tersebut yang secara konstan diekspresikan lebih rendah pada plasenta ibu hamil dengan preeklampsia berat.

Hung et al. melakukan studi untuk membandingkan ekspresi 5 protein bcl-2 family yaitu $\mathrm{BCl}_{2}, \mathrm{BCl}_{\mathrm{xL}_{\mathrm{L}}}, \mathrm{Bax}, \mathrm{Bak}$ dan Bad setelah jaringan plasenta kehamilan normal dikultur dalam suasana hipoxia (2\% O2), prolong hypoxia-reoxygenation $(\mathrm{HR})$, dan normoxic $(8 \%$ O2) sebagai kontrol. Hasilnya didapatkan peningkatan ekspresi Bax, dan Bak mRNA, dan penurunan ekspresi Bcl- ${ }_{2}$ mRNA. Tidak terdapat perubahan ekspresi pada $\mathrm{BCL}{ }_{\mathrm{xL}}$ dan Bad setelah oksigen stress dibandingkan pada yang kontrol normoxic.

Levi $\mathrm{R}$ et al. melakukan studi untuk membuktikan hipotesisnya bahwa hipoksia dapat menginduksi apotosis pada trofoblas. Trofoblas diambil dari jaringan plasenta wanita hamil cukup bulan tanpa komplikasi kehamilan yang kemudian dikultur sampai dengan 72 jam pada kondisi standar (PO2=120 mmHg) atau hipoksia (PO2 <15 $\mathrm{mmHg}$ ). Paparan kondisi hipoksia 24 jam ditandai dengan peningkatan apoptosis trofoblas. Apoptosis diikuti dengan peningkatan ekspresi P53 dan Bax dan penurunan ekspresi $\mathrm{Bcl}_{2}{ }^{9},{ }^{9,10}$

Di Indonesia, Keman dalam penelitiannya membandingkan ekspresi p53, Bcl- ${ }_{2}$ dan indeks apoptosis trofoblas pada preeklampsia/ eklampsia dan kehamilan normal. Penelitian ini merupakan studi laboratorium secara potong lintang dengan sampel jaringan trofoblas berasal dari biopsi jaringan plasenta preeklampsia $(n=20)$ dibandingkan dengan kehamilan normal $(n=20)$. Hasil yang diperoleh adalah terdapat perbedaan yang signifikan ekspresi protein $\mathrm{Bcl}_{2}$ dan p53 pada preeklampsia dibandingkan kehamilan normal dan jumlah sel trofoblas yang mengalami apoptosis pada jaringan trofoblas preeklampsia atau eklampsia lebih tinggi dari kehamilan normal. ${ }^{3}$

\section{METODE}

Penelitian dilakukan menggunakan desain studi potong lintang. Subyek penelitian berasal dari dua kelompok yaitu kelompok preeklampsia berat dan kelompok normotensi. Populasi penelitian adalah penderita preeklampsia berat dan kehamilan normotensi dengan usia kehamilan 28 - 40 minggu. Terhadap mereka terlebih dahulu dimintakan persetujuan untuk dilibatkan dalam penelitian.

Kriteria inklusi adalah pasien preeklampsia berat dan kehamilan normotensi dengan umur kehamilan 28-40 minggu dan setuju untuk diteliti. Kriteria eksklusi adalah pasien dengan penyakit penyerta (korioamnionitis, hipertensi kronik, diabetes mellitus, penyakit jantung).

Setiap pasien diambil sampel jaringan plasenta dengan cara yang sama, kemudian dikirim ke laboratorium histologi FK UGM untuk dilakukan pengecatan secara immunohistokimia pada pemeriksaan ekspresi protein $\mathrm{BCl}_{2}$ dan $\mathrm{BCl}_{-\mathrm{XL}}$.

\section{HASIL DAN PEMBAHASAN}

Pengumpulan sampel penelitian dilakukan selama 6 bulan yang dimulai pada bulan Oktober 2011 sampai dengan bulan Maret 2012. Dalam penelitian ini didapatkan 81 plasenta yang memenuhi syarat sebagai subyek penelitian yang terdiri dari 43 plasenta dari kehamilan dengan preeklampsia berat dan 38 plasenta dari kehamilan normotensi. Ekspresi protein $\mathrm{Bcl}_{2}$ dan $\mathrm{BCl}_{\mathrm{XL}}$ diukur dengan cara semiquantitative immunohistochemical scoring system (HSCORE). Penghitungan nilai HSCORE dilakukan oleh dua orang pemeriksa dan dilakukan uji kesesuaian antar observer atau uji konsistensi dengan Intraclass Correlation Coefficient (ICC). Setelah 
dilakukan uji ICC, didapat nilai ICC untuk ekspresi protein $\mathrm{BCl}_{2}$ adalah 0.998, sedangkan untuk $\mathrm{BCl}_{\mathrm{XL}}$ didapatkan nilai ICC 0.88. Ekspresi $\mathrm{BCl}_{2}$ dan $\mathrm{BCl}_{-\mathrm{xL}}$ dilihat dengan menggunakan mikroskop pembesaran kuat (400x) pada lima lapang pandang pada masing-masing sampel. Perubahan warna kecoklatan pada sel-sel trofoblas di desidua dengan intensitas bervariasi menunjukkan adanya ekspresi $\mathrm{Bcl}_{2}$ dan $\mathrm{Bcl}_{-{ }_{\mathrm{XL}}}$.
Pada tabel 1 ditampilkan karakteristik subyek penelitian, dimana kelompok variabel usia ibu dan paritas tidak didapatkan perbedaan bermakna secara statistik ( $p>0.05)$. Terdapat perbedaan pada rerata usia kehamilan, tekanan darah sistolik, tekanan darah diastolik dan mean arterial pressure (MAP) yang secara statistik bermakna antara kelompok preeklampsia berat dan normotensi.

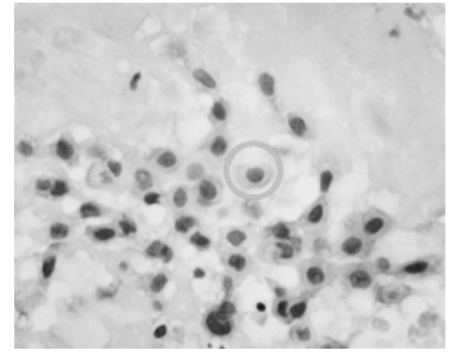

Ekspresi $\mathrm{B}_{\mathrm{Cl}-2}$ dengan intensitas 0

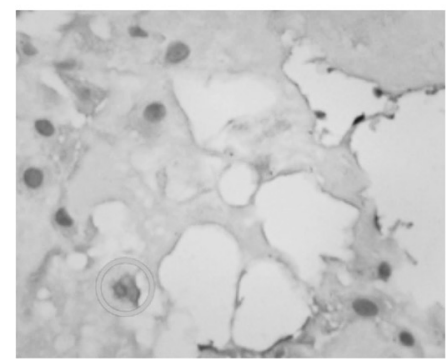

Ekspresi $\mathrm{B}_{\mathrm{Cl}-2}$ dengan intensitas 2

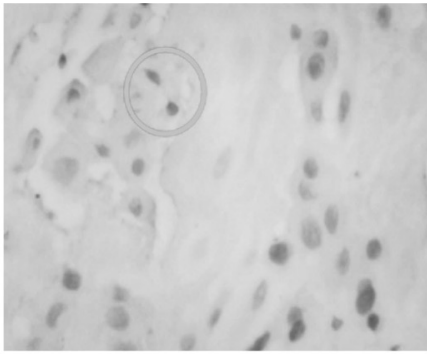

Ekspresi $\mathrm{B}_{\mathrm{Cl}-2}$ dengan intensitas 1

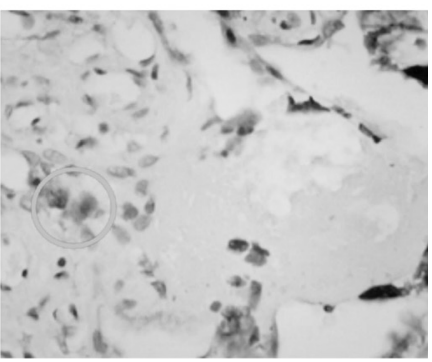

Ekspresi $\mathrm{B}_{\mathrm{Cl}-2}$ dengan intensitas 3

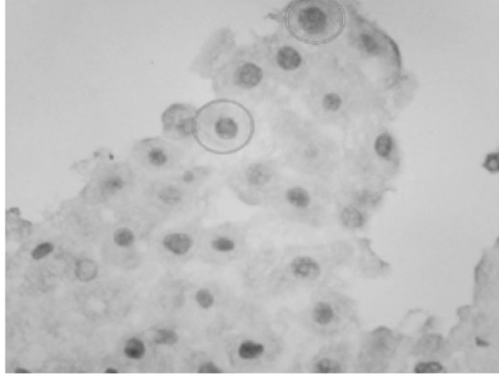

Ekspresi $\mathrm{B}_{\mathrm{Cl}-\mathrm{XL}}$ dengan intensitas 1

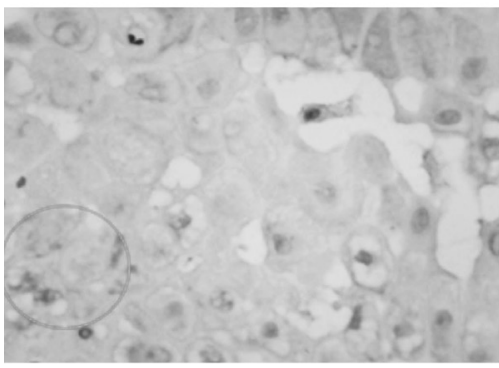

Ekspresi $\mathrm{B}_{\mathrm{Cl}-\mathrm{XL}}$ dengan intensitas 3
Gambar 1. Intensitas warna pengecatan protein $\mathrm{BCl}-2$
Gambar 2. Intensitas warna pengecatan protein $\mathrm{BCl}-\mathrm{xL}$
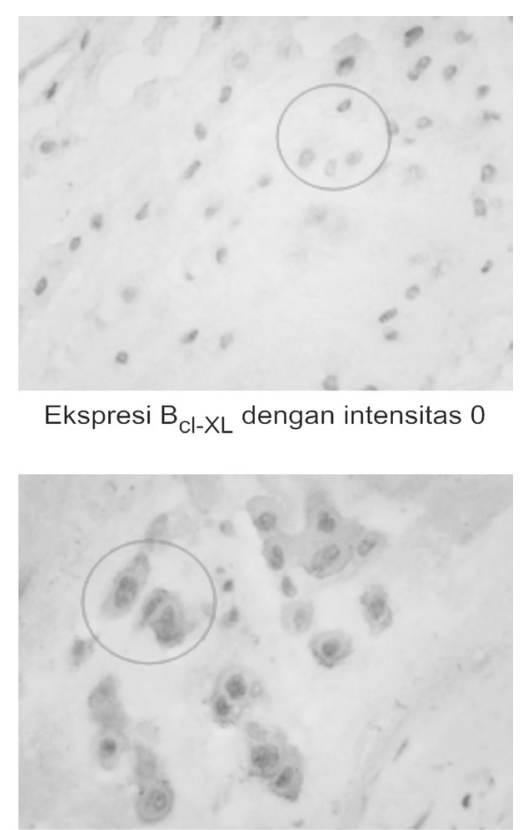

Ekspresi $\mathrm{B}_{\mathrm{Cl}-\mathrm{XL}}$ dengan intensitas 2 
Tabel 1. Karakteristik subyek kedua kelompok penelitian

\begin{tabular}{lccc}
\hline \multirow{2}{*}{ Variabel } & $\begin{array}{c}\text { Preeklamsia } \\
\text { Berat } \\
(\mathrm{n}=43)\end{array}$ & $\begin{array}{c}\text { Nomotensi } \\
(\mathrm{n}=38)\end{array}$ & $\mathrm{p}$ \\
\cline { 2 - 3 } & Mean \pm SD & Mean \pm SD & \\
\hline Usia ibu & $28,4 \pm 6,8$ & $28,4 \pm 7,1$ & 0 \\
Paritas & $0,6 \pm 0,8$ & $1,0 \pm 1,3$ & 0,13 \\
Usia kehamilan & $36,0 \pm 2.5$ & $38,6 \pm 1,1$ & 0,00 \\
Sistolik & $166,7 \pm 20,8$ & $114,2 \pm 7,2$ & 0,00 \\
Diastolik & $106,4 \pm 17,4$ & $76,3 \pm 6,7$ & 0,00 \\
MAP & $126,5 \pm 16,8$ & $88,7 \pm 6,4$ & 0,00 \\
BMI & $28,1 \pm 5,4$ & $25,9 \pm 4,3$ & 0,06 \\
\hline
\end{tabular}

Perbandingan rerata ekspresi protein $\mathrm{Bcl}-$ ${ }_{2}$ dan $\mathrm{BCl}_{\mathrm{xL}}$ kelompok preeklampsia berat dan normotensi pada tabel 2 menunjukkan bahwa rerata ekspresi kedua protein pada kelompok preeklampsia berat lebih rendah dan bermakna secara statistik dibandingkan kelompok normotensi $(p=0,00)$ dengan beda rerata 0,076 (Cl 95\% 0,046-0,104) untuk Bcl- ${ }_{2}$ dan 0,42 (Cl $95 \% 0,47-0,36)$ untuk Bcl-${ }_{x L}$.

Tabel 2. Perbandingan Ekspresi Protein $\mathrm{Bcl}_{2}{ }_{2}$ dan $\mathrm{Bcl}_{\mathrm{xL}}$ Plasenta Kehamilan Preeklampsia Berat Dibandingan Dengan Kehamilan Normotensi

\begin{tabular}{|c|c|c|c|c|}
\hline \multirow[t]{2}{*}{ Variabel } & $\begin{array}{c}\text { Preeklamsia } \\
\text { Berat } \\
(n=43)\end{array}$ & $\begin{array}{l}\text { Nomotensi } \\
\quad(n=38)\end{array}$ & $\begin{array}{c}\text { Perbedaan rerata } \\
\text { (Cl 95\%) }\end{array}$ & $p$ \\
\hline & Mean \pm SD & Mean \pm SD & & \\
\hline $\begin{array}{l}\text { Ekspresi } \\
\text { Bcl-2 }\end{array}$ & $1,03 \pm 0,04$ & $1,10 \pm 0,08$ & $\begin{array}{c}0,076 \\
(0,046-0,104)\end{array}$ & 0,00 \\
\hline $\begin{array}{l}\text { Ekspresi } \\
\text { Bcl-XL }\end{array}$ & $1,29 \pm 0,12$ & $1,71 \pm 0,14$ & $\begin{array}{c}0,42 \\
(0,47-0,36)\end{array}$ & 0,00 \\
\hline
\end{tabular}

Dengan membagi umur kehamilan dalam kelompok preterm dan aterm, pada tabel 3 dan 4 dibawah menunjukkan terdapat perbedaan rerata ekspresi protein $\mathrm{Bcl}_{2}$ dan $\mathrm{Bcl}_{\mathrm{XL}}$ antara umur kehamilan preterm dan aterm dengan nilai $p<0,05$.
Pada tabel 5 dan 6 di bawah menunjukkan bahwa terdapat perbedaan rerata ekspresi protein $\mathrm{Bcl}_{2}$ dan $\mathrm{Bcl}_{\mathrm{XL}}$ antara kelompok preeklamsia berat dan normotensi baik pada saat umur kehamilan preterm maupun aterm dengan nilai $p<0,05$. 
Tabel 3. Hubungan antara umur kehamilan dengan ekspresi protein $\mathrm{Bcl}_{-}$

\begin{tabular}{lccc}
\hline & $\begin{array}{c}\text { Jumlah Sampel } \\
(\mathrm{n}=80)\end{array}$ & Ekspresi Bcl-2 & $\mathrm{p}$ \\
\hline Preterm & 28 & $1,03 \pm 0,03$ & 0,000 \\
Aterm & 52 & $1,08 \pm 0,08$ & \\
\hline
\end{tabular}

Tabel 4. Hubungan antara umur kehamilan dengan ekspresi protein $\mathrm{Bcl}_{\mathrm{xL}_{\mathrm{L}}}$

\begin{tabular}{lccc}
\hline & $\begin{array}{c}\text { Jumlah Sampel } \\
(\mathrm{n}=81)\end{array}$ & Ekspresi Bcl-xl & $\mathrm{p}$ \\
\hline Preterm & 28 & $1,32 \pm 0,14$ & 0,000 \\
Aterm & 52 & $1,60 \pm 0,23$ & \\
\hline
\end{tabular}

\section{PEMBAHASAN}

Penelitian tentang perbandingan ekspresi $\mathrm{Bcl}-2$ dan $\mathrm{Bcl}-\mathrm{x}_{\perp}$ pada trofoblas sejauh ini belum penulis dapatkan. Ekspresi Bcl-x $\mathrm{L}_{\mathrm{L}}$ pernah diteliti pada pasien karsinoma hepatoseluler. Pada penelitian ini didapatkan ekspresi $\mathrm{Bcl}-2$ dan

Tabel 5. Hubungan antara preeklamsia berat dan $\mathrm{BCl}_{2}$ dengan mengendalikan umur kehamilan

\begin{tabular}{llccc}
\hline Umur kehamilan & \multicolumn{1}{c}{ Variabel } & $\mathrm{n}$ & Ekspresi Bcl-2 & $\mathrm{p}$ \\
\hline \multirow{2}{*}{ Preterm } & Preeklamsia berat & 27 & $1,03 \pm 0,03$ & \multirow{2}{*}{0,008} \\
\cline { 2 - 4 } & Normotensi & 1 & $1,08 \pm-$ & \\
\hline \multirow{2}{*}{ Aterm } & Preekalmsia berat & 16 & $1,04 \pm 0,06$ & \multirow{2}{*}{0,005} \\
\cline { 2 - 4 } & Normotensi & 36 & $1,11 \pm 0,08$ & \\
\hline
\end{tabular}

Tabel 6. Hubungan antara preeklamsia berat dan $\mathrm{Bcl}_{\mathrm{xL}}$ dengan mengendalikan umur kehamilan

\begin{tabular}{llccc}
\hline Umur kehamilan & \multicolumn{1}{c}{ Variabel } & $\mathrm{n}$ & Ekspresi Bcl-2 & $\mathrm{p}$ \\
\hline \multirow{2}{*}{ Preterm } & Preeklamsia berat & 27 & $1,30 \pm 0,13$ & \multirow{2}{*}{0,015} \\
\cline { 2 - 4 } & Normotensi & 1 & $1,65 \pm-$ & \\
\hline \multirow{2}{*}{ Aterm } & Preekalmsia berat & 16 & $1,30 \pm 0,11$ & \multirow{2}{*}{0,000} \\
\cline { 2 - 4 } & Normotensi & 36 & $1,27 \pm 0,14$ & \\
\hline
\end{tabular}


Bcl- $x_{L}$ pada wanita preeklampsia lebih rendah dibandingkan dengan kehamilan normotensi. Perbedaan yang ditunjukkan bermakna secara statistik $(p=0.00)$. Hal ini sesuai dengan hasil penelitian oleh Schawn dkk menyatakan bahwa ekspresi protein antiapoptosis (Bcl-2 dan Bclxl) lebih rendah pada penderita preeklampsia, dimana apoptosis dipicu oleh keadaan hipoksia. ${ }^{6}$ Allaire menyimpulkan dalam penelitiannya bahwa kehadiran marker apoptosis dapat digunakan sebagai penanda adanya hipoksia intrauterine, dan mendapatkan ekspresi $\mathrm{Bcl}-2$ dan $\mathrm{Bcl}-\mathrm{x}_{\mathrm{L}}$ rendah sebagai antiapoptosis dari kelompok $\mathrm{Bcl}-2 .{ }^{11}$

Beda rerata ekspresi protein pada kedua kelompok diketahui untuk $\mathrm{Bcl}-2$ adalah 0,076 (Cl 95\% 0,046-0,104), sedangkan Bcl-xl adalah 0,42 ( $\mathrm{Cl} 95 \%$ 0,47 - 0,36). Dari data tersebut diketahui bahwa beda rerata ekspresi protein Bcl-2 pada preeklampsia dan normotensi lebih rendah $(0,076)$ dibandingkan beda rerata ekspresi protein $\mathrm{Bcl}-\mathrm{xl}(0,42)$ pada preeklampsia dan normotensi. Hung dalam penelitiannya mendapatkan adanya penurunan ekspresi protein $\mathrm{Bcl}-2$ dan tidak ada perubahan dalam ekspresi protein $\mathrm{Bcl}-\mathrm{xl}$. Belum diketahui dengan jelas mengenai adanya perbedaan ekspresi $\mathrm{Bcl}-2$ dan $\mathrm{Bcl}-\mathrm{xl}$, padahal kedua protein antiapoptosis tersebut mempunyai peran yang sama dan pada jalur apoptosis yang sama. ${ }^{8,12}$

Dalam keadaan normal aktivitas apoptosis juga meningkat sesuai usia kehamilan, sehingga ekspresiBcl-_ dan $\mathrm{Bcl}_{\mathrm{xL}}$ dalam keadaan normaljuga menurun seiring bertambahnya usia kehamilan. Pada uji variabel luar dengan variabel tergantung pada tabel 3 dan 4 diatas, menunjukkan adanya perbedaan rerata ekspresi protein $\mathrm{Bcl}_{2}(p=0,000)$ dan $\mathrm{BCl}_{x \mathrm{~L}}(\mathrm{p}=0,000)$ antara umur kehamilan preterm dan aterm. Pada kelompok preterm rerata ekspresi protein $\mathrm{Bcl}_{2}(1,03 \pm 0,03)$ dan $\mathrm{Bcl}$ ${ }_{x L}(1,32 \pm 0,14)$ justru lebih rendah dibandingkan rerata ekspresi protein $\mathrm{Bcl}_{2}(1,08 \pm 0,08)$ dan $\mathrm{Bcl}$ ${ }_{x L}(1,60 \pm 0,23)$ pada kelompok aterm. Hasil yang berbeda ini terjadi karena pada data penelitian ini sebagian besar kelompok preterm berasal dari sampel preeklamsia (27 sampel 28 sampel total kelompok preterm). Preeklamsia diketahui memang mengekspresikan protein antiapoptosis lebih rendah dibandingkan kelompok normotensi pada umur kehamilan yang sama. Tabel 5 dan 6 mempertegas adanya perbedaan rerata ekspresi protein $\mathrm{BCl}_{2}$, dan $\mathrm{Bcl}_{\mathrm{XL}}$ antara kelompok preeklamsia berat dan normotensi baik saat usia kehamilan preterm maupun aterm. Dari data ini dapat diartikan bahwa faktor preeklamsia berat lebih mempengaruhi ekspresi protein $\mathrm{Bcl}_{2}$ dan $\mathrm{BCl}_{\mathrm{xL}}$ dibandingkan faktor umur kehamilan.

\section{KESIMPULAN DAN SARAN}

Beda rerata ekspresi protein $\mathrm{Bcl}-2$ dan $\mathrm{Bcl}-$ $x_{L}$ lebih rendah pada kehamilan preeklamsia berat dibandingkan kehamilan normotensi. Beda rerata ekspresi protein $\mathrm{Bcl}-2$ lebih rendah dibandingkan beda rerata ekspresi protein $\mathrm{Bcl}-\mathrm{xl}$. Preeklamsia berat lebih berpengaruh terhadap ekspresi protein $\mathrm{BCl}_{2}$ dan $\mathrm{BCl}_{-{ }_{\mathrm{L}}}$ dibandingkan umur kehamilan

\section{DAFTAR PUSTAKA}

1. Girsang ES. 2004. Analisis tekanan darah dan proteinuria sebagai faktor prognosis kematian maternal dan perinatal pada preeklamsia berat dan eklamsia. Tesis PPDS ObsGin FK USU, RSUP H Adam Malik/RSUD Dr Pringadi Medan.

2. Sofoewan S. 1998. Preeklampsia di Beberapa Rumah Sakit DI Indonesia, Patogenesis, dan Kemungkinan Pencegahan. Pidato Pengukuhan Jabatan Guru Besar pada Fakultas Kedokteran Universitas Gadjah Mada, Yogyakarta

3. Keman K, Presetyorini N, Langgar M J. Perbandingan ekspresi p53, Bcl-2, dan Indeks Apoptosis Trofoblas pada Preeklampsia/Eklampsia dan Kehamilan Normal. Majalah Obstetri dan Ginekologi Indonesia, 2009; 33-3, pp.151-159.

4. Roeshadi HR. Hipertensi dalam Kehamilan, dalam IImu Kedokteran Feto-maternal, edisi perdana, hal 494-99, Himpunan Kedokteran Fetomaternal, 
Perkumpulan Obstetri dan Ginekologi Indonesia, Surabaya, 2004.

5. Noris M, Perico N, Remuzzi G. Mechanism of Disease: Pre-eclampsia, Nat Clin Pract Nephrol. 2005 Dec;1(2):98-114

6. Shawn L., Straszewski-Chavez, Vikki MA., Mor G. The Role of Apoptosis in The Regulation of Trophoblast Survival and Differentiation During Pregnancy, Endocrine reviews. 2005; 26(7): 877-97.

7. Dash P. Apoptosis, Basic Medical Sciences, St George's, University of London, 2009.

8. Hung TH., Chen SF., Liou JD., Hsu JJ, Li MJ, Yeh YL et al. Bax, Bak and Mitochondrial Oxidants are Involved inHypoxia-reoxygenation-induced Apoptosis in Human Placenta. Placenta 2008; 29: 65-83.
9. Levi Retal. Apoptosis In Human cultured Trophoblast is Enhanched by hypoxia and diminished by Epidermal Growth factor, Am J Physiol Cell Physiol, 2000; C982-C988.

10. Churchill D and Duley L. Interventionist versus expectant for severe preeclampsia before term (Review), Cochrane Database of Systematic Review, 2002; issue 3. Art, No. CD003106.

11. Allaire AD., Ballenger KA., Well SR., McMohan MJ, Lessey BA. Placental Apoptosis in Preeclampsia, Obstetrics \& gynecology, 2000; 96: 271-76.

12. De Angelis PM., Stokke T, Thorstensen L, Lothe RA, Clausen OP. Apoptosis and Expression of Bax, $\mathrm{Bcl}-\mathrm{x}$ and $\mathrm{Bcl}-2$ apoptotic regulatory protein in colorectal carcinomas, and asscociation with p53 genotype/ phenotype, Mol Path 1998; 51(5) 254-261. 